Egyptian Journal of Aquatic Biology \& Fisheries

Zoology Department, Faculty of Science,

Ain Shams University, Cairo, Egypt.

ISSN $1110-6131$

Vol. 25(1): 293 - 312 (2021)

www.ejabf.journals.ekb.eg

\title{
Identifying and categorizing potential indicator macroinvertebrate taxa in a southern Nigerian reservoir using a multivariate approach
}

\author{
Ekikhalo C. Osimen ${ }^{1}$, Luckey A. Elakhame ${ }^{1}$, \\ Augustine O. Edegbene ${ }^{1,2} *$ and Joshua I. Izegaegbe ${ }^{1}$ \\ ${ }^{1}$ Department of Zoology, Ambrose Alli University, Ekpoma, Nigeria. \\ ${ }^{2}$ Institute for Water Research, Rhodes University, Grahamstown, South Africa. \\ *Corresponding author: ovieedes@gmail.com
}

\section{ARTICLE INFO}

Article History:

Received: Nov. 10, 2020

Accepted: Dec. 30, 2020

Online: Jan. 24, 2021

Keywords:

Biomonitoring tools,

Biological classes,

Macroinvertebrates,

indicator taxa,

Centroptilum spp.,

Mytilus dubia,

Multivariate analysis.

\section{ABSTRACT}

Anthropogenic activities within and around freshwater ecosystems are serious threats to the structural and functional assemblages of aquatic biodiversity. In the present study, an identification and categorization of the potential sensitive and tolerant macroinvertebrate taxa in a southern Nigerian reservoir were assorted, using multivariate approach. Macroinvertebrates and selected physico-chemical variables were sampled monthly in four sites for a period of two years (January 2009 to December 2010). PCA performed classified Site 1 as less impacted, and Site 4 as heavily impacted. Elevated mean values of pollution indicating physico-chemical variables such as $\mathrm{BOD}_{5}$, phosphate and TSS were recorded in Site 4, and an increased concentration of DO was recorded in Site 1. Diptera dominated the 28 taxa of macroinvertebrate that were recorded in the entire study period, noting that the absolute abundance of Diptera taxa was higher at Site 4. NMDS revealed Sites 1 and 2 to form cluster B portraying similarity in the assemblage structure of taxa recorded in both sites, and cluster A formed a mixture of macroinvertebrate taxa assemblages from all the sampled sites. CCA and further categorization analyses performed identified and classified Centroptilum spp. to be very sensitive to pollution, while Mytilus dubia was the only taxon that was identified and classified as very tolerant of pollution. Overall the study pointed out the usefulness of using multivariate approach in identifying and classifying potential indicator taxa for effective monitoring and management of freshwater ecosystem most especially in Sub- Saharan Africa where studies of this kind are still scanty.

\section{INTRODUCTION}

Anthropogenic activities within and around freshwater ecosystems e.g. rivers, streams, lakes, and reservoirs are seriously affecting the structural and functional assemblages of aquatic biodiversity (Parienté, 2017; Edegbene et al., 2020). Traditionally, the effects of anthropogenic activities resulting in pollution in freshwater ecosystems are assessed by measuring and analyzing values of physico-chemical variables (Adakole \& Anunne, 2003; Palmer et al., 2004). The relationship of physico- 
chemical variables and aquatic biota have also been estimated for decades to evaluate the impacts of anthropogenic activities in aquatic ecosystems (Palmer et al., 2004; Arimoro et al., 2015; Edegbene et al., 2015). In recent times, biological monitoring tools have replaced phisico-chemistry, taxa abundance, and diversity to assess and monitor freshwater ecosystems in developed countries; e.g. biological monitoring working party( BMWP) (Walley \& Hawkes, 1996), south Africa scoring system(SASS) in sub-Sahara Africa (Dickens \& Graham, 2002), and Tanzania scoring system(TARIS) ( Kaaya $\boldsymbol{e t}$ al., 2015). In Nigeria, such biological monitoring tools have not been developed for evaluating the negative impacts of anthropogenic activities on aquatic ecosystems except the recent macroinvertebrate-based multimetric indexes particularly developed for urban rivers in the Niger Delta region of Nigeria (Edegbene et al., 2019a) and River Chanchaga in North Central region of Nigeria (Edegbene et al., 2019b). The above mentioned biomonitoring tools are important in terms of predicting gradients of pollution in freshwater ecosystems (Odume et al., 2016).

Despite the fact that physico-chemical variables are significant to assess the health of aquatic ecosystems, high financial implication and requisite expertise are needed coupled with the rigorous analytic procedures and chemicals required in analyzing physico-chemical variables. Therefore, aquatic health assessment method of using physico-chemically-based approach is not economical and in most times very difficult to analyze. Furthermore, the effects of anthropogenic activities on freshwater ecosystems cannot be assessed entirely depending on physico-chemically-based approach due to the fact that physico-chemically-based approach is sticktly contributed to the time and spot in which the water sample was collected for the analysis (Palmer et al., 2004; Odume $\boldsymbol{e t}$ al., 2016; Edegbene et al., 2019a). Hence, the need to identify and classify biological parameters for rapid and easy biomonitoring of aquatic health is deeply required. Biomonitoring takes into account a holistic measure of multiple parameters, e.g. physical, chemical and biological stressors, and their effects on the structural and functional assemblage of freshwater ecosystems and their inherent biota (Bonada et al., 2006).

Several aquatic biota; e.g. fish, macroinvertebrate, plankton (Ogidiaka et al., 2013; Katsiapi et al., 2016; Gieswein et al., 2019) have been examined in assessing the effect of anthropogenic activities on freshwater ecosystem. Among the biota used, macroinvertebrates are the most explored due to their key position in aquatic food chain and food web (Odume et al., 2016; Edegbene et al., 2019b). Macroinvertebrate-based biological monitoring is done by compiling the structural and functional assemblage of several groups of the macroinvertebrates (Lenat \& Resh, 2001; Adakole \& Anunne, 2003; Edegbene et al., 2020b). Furthermore, due to the fact that taxa of macroinvertebrates respond differently to anthropogenic influences, a more sophisticated approach is required to determine their level of sensitivity and tolerance to pollution in freshwater ecosystems, including rivers, streams, lakes and reservoirs (Lenat \& Resh, 2001; Edegbene \& Arimoro, 2012). For instance, rivers, streams, lakes and reservoirs sites with high abundance of Diptera and Oligochaeta are mainly interpreted as being polluted as Diptera and Oligochaeta are tolerant to pollution (Adeogun \& Fafioye 2011; Arimoro et al., 2015). However, recent studies have shown some species in the Diptera families of Simuliidae and Chironomidae to be sensitive to pollution as their absence were noticed in gold mining and agriculturally impacted sites (Edegbene $\boldsymbol{e t}$ al., 2015; 
Shimba \& Jonah, 2016). Based on variation recorded in the sensitivity and tolerance of some group of macroinvertebrates, identifying and classifying macroinvertebrate taxa as potential biological indicators is of paramount importance at this stage most especially for reservoirs in Sub-Saharan Africa, Nigeria, inclusively, where there is paucity of information regarding the sensitivity and tolerance of macroinvertebrate taxa (Odume, 2016; Edegbene, 2020). Therefore, this study was carried out in Ojirami reservoir to address the following specific objectives: (i) to assess the level of impairment to which each sampling site has been subjected; (ii) to visualize the structural assemblage pattern of identified macroinvertebrate taxa in relation to sampling sites and months; and (iii) to identify and classify macroinvertebrate taxa into biological classes for biological health assessments purposes of aquatic ecosystems.

\section{MATERIALS AND METHODS}

\section{Description of study area and sites}

Ojirami Reservoir in Ojirami Dam is located in Akoko-Edo, Edo State, southsouth Nigeria. The reservoir is the oldest man-made lake in the State, constructed between 1971 and 1974, to supply water to the communities of Akoko Edo, Owan and Etsako Local Government Areas at an output capacity of $245 \mathrm{~m}^{3} /$ hour. The reservoir lies between latitude $7^{\circ} 18^{\prime \prime}$ to $7^{\circ} 20^{\prime \prime}$ North and longitude $6^{\circ} 09^{\prime \prime}$ to $6^{\circ} 11$ East of the Equator. It is fed by River Onyami and River Ese which flow from Kogi State down south, in addition to four tributary streams; Somorika, Ebukumu, Ekenireme and Ikekpa (Figure 1). The climatic condition of Ojirami Reservoir falls within the warm-humid tropical climate with two seasons: wet season (April - October) and dry season (November March). Mean air temperature during the study was $30.5^{\circ} \mathrm{C}$, and total annual rainfall was $1,250.22 \mathrm{~mm}$ in 2009 and 1,439.47 $\mathrm{mm}$ in 2010 (Osimen et al., 2017). The reservoir stores water for Ojirami Dam water treatment plant under the management of the Edo State Urban Water Board.

Human activities within and around the reservoir include swimming, bathing, washing of clothes and utensils. The reservoir is a center of attraction for eco-tourism, and a site for students' excursion and research. Fishing and crop farming activities are the main agricultural activities within the reservoir catchment. According to fishers, fish catches have reduced drastically due to siltation and constant release of water from the reservoir (a management strategy to prevent dam collapse). Other sources of anthropogenic influence around the reservoir catchment include run-off from settlements that are informal, unauthorized domestic use of water in the reservoir, and few industrial sites (upstream) for exploitation of metallic minerals. Pollution from these anthropogenic activities is threatening the structural composition and diversity of aquatic biota and the general health of the Ojirami Reservoir. Vegetation around the reservoir comprises of grasses and woody trees. Dominant macrophytes species in the reservoir include Leersia hexandra, Polygomum salicifolium and Rhyncospora species (Adesina et al., 2010). The pelagic zone of the reservoir is free of aquatic macrophytes except for few Nymphae lotus in the creek. Different shrubs and woody species such as Danielia oliveri, Albiza zygia and Isoberlina doka, and few oil palm trees are found on the hilly side. Cashew and oil palm (Elaeis guineensis) plants are some of the riparian vegetation around the reservoir catchment. 


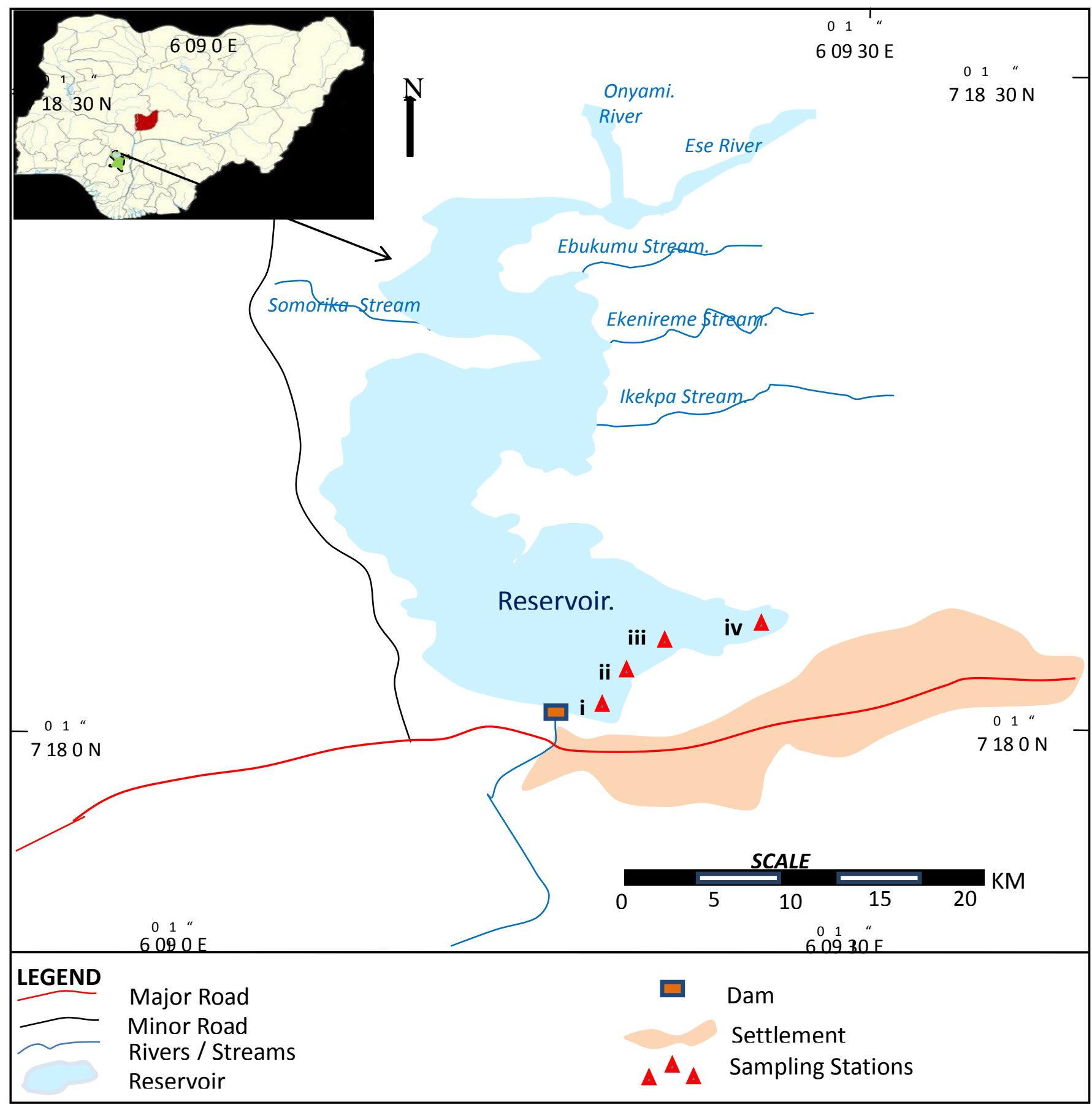

Figure 1: Ojirami Reservoir showing sampling sites (map of Nigeria insert)

Four sites were selected for this study including Sites $1-4$ along a one kilometer stretch of the eastern part of Ojirami reservoir bankroot biotope. Site 1 was located about $300 \mathrm{~m}$ from the Ojirami Dam embankment. The site was located in a section of the reservoir with intense anthropogenic impact in which fetching of water for domestic use, washing of clothes, bathing and swimming, and fishing/fish landing are the major human activities noticed there. There is a foot path from the village which serves as access route by the fish mongers to patronize the fishermen and the villagers for other activities. Site 2 was 
located about $200 \mathrm{~m}$ after Site 1 with evidence of mild anthropogenic influences such as fishing, bathing, swimming, and washing by inhabitants within the reservoir catchment. Site 3 was located at the middle reach of the reservoir with intense fishing and other agricultural cropping activities. Also pronounced in Site 3 are activities such as bathing, swimming, washing and open defecation. Site 4 was situated at the downstream of the reservoir which is very close to farmlands, and intense fishing activities. Site 4 is also close to industries that engage in metallic mineral exploitation. Additionally, anthropogenic activities evident in Site 3 were all present in Site 4 at an elevated rate.

\section{Analysis of physico-chemical variables and sampling of macroinvertebrates}

Physico-chemical variables and macroinvertebrates data were collected once per month for a period of two years (January 2009 - December 2010). Physico-chemical variables analyzed for the study include water temperature, depth, electrical conductivity (EC), turbidity, $\mathrm{pH}$, dissolved oxygen (DO), five day biochemical oxygen demand $\left(\mathrm{BOD}_{5}\right)$, total dissolved solids (TDS), total suspended solids (TSS) and phosphate. Water temperature and depth were measured using mercury-in-glass-thermometer (measured in ${ }^{\circ} \mathrm{C}$ ) and a calibrated stick (measured in metre), respectively. Electrical conductivity and $\mathrm{pH}$ were measured with a portable hand held HANNA HI 9913001/1 instrument. Dissolved oxygen was measured at each sampling site per sampling expedition using DO metre (YSI 55), while turbidity was measured using a WGZ-B model turbidity metre. Water samples were collected in a sterile $50 \mathrm{ml}$ sample bottles on each sampling occasion for the determination of phosphate, TDS, TSS and $\mathrm{BOD}_{5}$ in the laboratory following APHA (1998) methods.

Simultaneously, with physico-chemical variables sampling, macroinvertebrates were sampled monthly by using a D-frame kick net of $500 \mu \mathrm{m}$ mesh size as modified in the study of Lazorchak et al. (1998). Macroinvertebrate samples were collected in various biotopes which include bank roots, silt, sand and stones. Three different samples of macroinvertebrate were collected for a period of five minutes at each biotope, thus a total of 12 samples (three samples X four biotopes) were collected from each site. On each sampling occasion all samples collected from different biotopes were pooled together as one composite sample, and thereafter preserved in $10 \%$ formalin in transparent well labeled containers before transferring to the laboratory for sorting, identification and counting. Identification of macroinvertebrates were estimated to lowest possible taxa using a binocular microscope under a magnification of X10 using available macroinvertebrate pictorial guides of Merritt and Cummins (1996); Day et al. (2003) and de Moor et al. (2003), and consultation of expert macroinvertebrate taxonomist. Voucher samples of macroinvertebrates were deposited at the Laboratory of Zoology Department of Ambrose Alli University, Ekpoma, Nigeria for future reference.

Descriptive statistic (mean \pm standard deviation, and range) of physico-chemical variables were computed using Palaentological statistical package (PAST) (Hammer et al., 2001). Global significant differences of each physico-chemical variable between sampled sites were tested using one-way permutational multivariate analysis of variance (PERMANOVA). Confirmation of significant differences between physico-chemical variables and sampled sites was recorded using one way analysis of variance (ANOVA) based on the calculated mean values of physico-chemical variables. Following the results 
of ANOVA, a post hoc test, using Turkey Honestly Significant difference (HSD), was computed to confirm sites that differed, based on means of the physico-chemical variables. Assumption and homogeneity of variance of the physico-chemical variables across the four sites were checked using Shapiro-Wilk's and Levene's tests (Derrick et al., 2018). PERMANOVA was computed using Primer software package version 6, and ANOVA, HSD and test for homogeneity (Shapiro-Wilk's and Levene's tests) were computed using PAST statistical package (Hammer et al., 2001). The correlation between the sampled sites and physico-chemical variables were visualized with Principal Component Analysis (PCA) using correlation matrix function. PCA was computed using vegan package within the R-programming environment ( $R$ Development Core Team, 2019).

\section{Structural assemblage of macroinvertebrates in relation to sampling sites and months}

The structural assemblage patterns of macroinvertebrate taxa throughout the study period in the four sampling sites were visualized using non-metric multidimensional scaling (NMDS) based on Bray-Curtis similarity. Macroinvertebrate taxa data were logarithmically transformed $(\log x+1)$ to avoid skewness of highly abundant taxa with regards to sampling sites. The NMDS were computed using PAST statistical package (Hammer et al., 2001).

\section{Relating taxa of macroinvertebrate and physico-chemical variables}

Canonical correspondence analysis (CCA) was used to correlate macroinvertebrate taxa and physico-chemical variables in a bid to visualize their pattern of distribution along the four sampling sites. Macroinvertebrate datasets were $\log (x+1)$ transformed and subjected to a test of unimodality using detrended correspondence analysis (DCA), and the DCA confirmed the dataset to be unimodal by returning a gradient length of $>3.0$ (ter Braak, 1995), hence CCA was employed for computing the ordination. A Monte Carlo permutation test at 999 permutation arguments was further computed to reveal the significant differences among the taxa, physico-chemical variables and sites on the CCA axes (Legendre \& Legendre, 2012). The CCA ordination and Monte Carlo permutation test were conducted on the vegan package using R-statistics (Oksanen et al., 2019; R Development Core Team, 2019).

\section{Identifying and categorizing potential sensitive and tolerant macroinvertebrate taxa}

The 28 macroinvertebrate taxa identified in the studied reservoir were classified into eight biological classes which include very tolerant (VT), tolerant (T), moderately tolerant (MT), slightly tolerant (ST), slightly sensitive (SS), moderately sensitive (MS), sensitive (S) and very sensitive (VS). Taxa sensitivity and tolerance were derived by correlating physico-chemical variables with macroinvertebrate taxa along the four sampling sites using CCA. Macroinvertebrate taxa scores were extracted from the CCA first axis owing to the fact that the CCA first axis explained over $99 \%$ variance of the total CCA variance. The exact biological classification was performed by calculating the inter-taxa distance of each macroinvertebrate taxa following a three-step approach. Firstly, by subtracting the coordinate scores of the lowest scoring taxa from the highest scoring taxa among the 28 identified macroinvertebrate taxa, and subsequently coordinate 
scores of the remaining taxa that were subtracted from the highest scoring taxa. Secondly, the calculated inter-taxa distances were further converted to percentage distances, then thirdly, a percentile distribution was used to classify macroinvertebrate taxa into one of the eight biological classes; namely, VT, T, MT, ST, SS, MS, S and VS with corresponding percentile distribution of $100^{\text {th }},<100-90^{\text {th }},<90-70^{\text {th }},<70-50^{\text {th }},<50-$ $40^{\text {th }},<40-20^{\text {th }},<20-10^{\text {th }}$ and $<10-0^{\text {th }}$, respectively. The approach employed in this study in classifying macroinvertebrate taxa into biological classes has earlier been used by Murphy et al. (2013) and Odume et al. (2016) who calculated distances of species along Axis 1 of CCA ordination. Similarly, Edegbene et al. (2019a and 2020b) recently applied this approach in categorizing river sites into pollution impact categories by extracting the coordinate scores of river sites on the first axis of PCA ordination.

\section{RESULTS}

\section{Descriptive statistical significance and correlation of physico-chemical variables with sampled sites}

The mean values of physico-chemical variables were not significantly different $(\mathrm{P}>$ 0.05) in all the sites sampled, except for DO and phosphate (Table 1). The decrease in value of DO in Site $4\left(3.5 \pm 1.23 \mathrm{mgl}^{-1}\right)$ corresponds to an exceptionally increased value of nutrient (phosphate) in Site $4\left(17.38+5.93 \mathrm{mgl}^{-1}\right)$. Marked increase in the mean values of TSS and $\mathrm{BOD}_{5}$ was observed in Site 4 (Table 1) compared to the remaining three sites. Mean values of water temperature and $\mathrm{pH}$ were relatively similar in all the four sampled sites. Turbidity was lower in Site $3(9.25 \pm 10.45$ NTU) compared to Sites 1, 2 and 4. Generally, physico-chemical, variables analysed in the present study, showed a fast deteriorating water quality in Site 4 compared to the other three sampled sites. Site 1 showed a relatively less impacted water quality condition among the four sites sampled.

Axis 1 of the PCA ordination explained a total variance of $99.84 \%$, with an Eigen value of 3.99. Site 1 was strongly positively correlated with depth, DO and water temperature on Axis 1, although the influence of depth and DO in structuring Site 1 was relatively higher than water temperature (Figure 2). Further on Axis 1, Sites 3 and 4 were strongly correlated with increasing concentration of $\mathrm{BOD}_{5}$, phosphate, turbidity, EC and TDS (Figure 2). Specifically, the structuring of Sites 3 and 4 level of impact were mainly influenced by increasing concentration of $\mathrm{BOD}_{5}$, phosphate and turbidity. Axis 2 of the PCA ordination explained $0.082 \%$ of the total PCA variance. Site 2 was strongly positively correlated with TSS and $\mathrm{pH}$ on Axis 2 (Figure 2). Based on the result revealed by the descriptive statistic and PCA ordination computed, Site 1 indicates a relatively less impacted site, and Site 2 was moderately impacted and Sites 3 and 4 were heavily impacted. 
Table 1: Mean \pm Standard Deviation (excluding $\mathrm{pH}$ ) of physico-chemical variables sampled in Ojirami Reservoir between January 2009 and December 2010. P-value and Fvalue as revealed by one-way analysis of variance (ANOVA). Physico-chemical variables per site with the same letters indicate no significant differences $(\mathrm{P}>0.05)$ as revealed by post hoc test (Turkey honestly significant difference, HSD).

\begin{tabular}{|c|c|c|c|c|c|c|}
\hline Physico-chemical variables & Site 1 & Site 2 & Site 3 & Site 4 & P-value & F-value \\
\hline Water temperature $\left({ }^{\circ} \mathrm{C}\right)$ & $\begin{array}{l}28.92 \pm 1.62 \\
(26-31)^{\mathrm{a}}\end{array}$ & $\begin{array}{l}28.92 \pm 1.56 \\
(27-31)^{\mathrm{a}}\end{array}$ & $\begin{array}{l}29.42 \pm 2.94 \\
(24-34)^{\mathrm{a}}\end{array}$ & $\begin{array}{l}29.25 \pm 2.42 \\
(25-34)^{\mathrm{a}}\end{array}$ & 0.9269 & 0.1535 \\
\hline Depth (m) & $\begin{array}{l}2.60 \pm 0.91 \\
(0.65-3.5)^{\mathrm{a}}\end{array}$ & $\begin{array}{l}2.14 \pm 0.72 \\
(0.62-3.0)^{\mathrm{a}}\end{array}$ & $\begin{array}{l}1.96 \pm 0.57 \\
(0.73-2.8)^{\mathrm{a}}\end{array}$ & $\begin{array}{l}2.22 \pm 0.81 \\
(0.62-3.5)^{\mathrm{a}}\end{array}$ & 0.2198 & 1.531 \\
\hline $\mathrm{pH}$ & $(5.2-8.2)$ & $(5.7-8.0)$ & $(6.9-8.5)$ & $(6.0-8.5)$ & 0.2403 & 1.453 \\
\hline Electrical Conductivity $\mu \mathrm{Scm}^{-1}$ & $\begin{array}{l}110 \pm 32.47 \\
(50-150)^{\mathrm{a}}\end{array}$ & $\begin{array}{l}110.83 \pm 31.75 \\
(50-140)^{\mathrm{a}}\end{array}$ & $\begin{array}{l}108.33 \pm 31.57 \\
(50-150)^{\mathrm{a}}\end{array}$ & $\begin{array}{l}106.67 \pm 36.01 \\
(50-150)^{\mathrm{a}}\end{array}$ & 0.9901 & 0.03762 \\
\hline Turbidity (NTU) & $\begin{array}{l}16.58 \pm 21.99 \\
(0-76)^{\mathrm{a}}\end{array}$ & $\begin{array}{l}17 \pm 22.25 \\
(1-66)^{\mathrm{a}}\end{array}$ & $\begin{array}{l}9.25 \pm 10.45 \\
(0-29)^{\mathrm{a}}\end{array}$ & $\begin{array}{l}15.08+21.35 \\
(1-65)^{\mathrm{a}}\end{array}$ & 0.7544 & 0.399 \\
\hline $\operatorname{TDS}\left(\mathrm{mgl}^{-1}\right)$ & $\begin{array}{l}54.08+15.92 \\
(25-70)^{\mathrm{a}}\end{array}$ & $\begin{array}{l}55.83+16.73 \\
(25-77)^{\mathrm{a}}\end{array}$ & $\begin{array}{l}54.67 \pm 16.37 \\
25-80)^{\mathrm{a}}\end{array}$ & $\begin{array}{l}52.58+19.08 \\
(25-79)^{\mathrm{a}}\end{array}$ & 0.973 & 0.07522 \\
\hline $\operatorname{TSS}\left(\mathrm{mgl}^{-1}\right)$ & $\begin{array}{l}8.58+16.54 \\
(0-52)^{\mathrm{a}}\end{array}$ & $\begin{array}{l}9.25 \pm 16.09 \\
(0-46)^{\mathrm{a}}\end{array}$ & $\begin{array}{l}8.92+13.59 \\
(0-48)^{\mathrm{a}}\end{array}$ & $\begin{array}{l}15.42 \pm 31.31 \\
(0-105)^{\mathrm{a}}\end{array}$ & 0.8247 & 0.3007 \\
\hline $\mathrm{DO}\left(\mathrm{mgl}^{-1}\right)$ & $\begin{array}{l}6.2 \pm 1.15 \\
(4.3-6.7)^{\mathrm{a}}\end{array}$ & $\begin{array}{l}4.43 \pm 0.83 \\
(3.4-5.8)^{b}\end{array}$ & $\begin{array}{l}4.23 \pm 0.73 \\
(3.1-5.4)^{b}\end{array}$ & $\begin{array}{l}3.5 \pm 1.23 \\
(2.9-5.7)^{\mathrm{c}}\end{array}$ & 0.746 & 0.4108 \\
\hline $\mathrm{BOD}_{5}\left(\mathrm{mgl}^{-1}\right)$ & $\begin{array}{l}1.51 \pm 0.9 \\
(0.1-2.9)^{\mathrm{a}}\end{array}$ & $\begin{array}{l}1.52 \pm 0.98 \\
(0.4-3.5)^{\mathrm{a}}\end{array}$ & $\begin{array}{l}1.39 \pm 0.78 \\
(0.4-2.8)^{\mathrm{a}}\end{array}$ & $\begin{array}{l}1.60 \pm 1.34 \\
(0.5-5.2)^{\mathrm{a}}\end{array}$ & 0.63 & 0.5819 \\
\hline Phosphate $\left(\mathrm{mgl}^{-1}\right)$ & $\begin{array}{l}7.57 \pm 6.14 \\
(1-20.1)^{\mathrm{a}}\end{array}$ & $\begin{array}{l}7.55 \pm 5.48 \\
(0.5-14.2)^{\mathrm{a}}\end{array}$ & $\begin{array}{l}7.41 \pm 5.37 \\
(1.28-14.8)^{\mathrm{a}}\end{array}$ & $\begin{array}{l}17.38+5.93 \\
(15.9-17.9)^{b}\end{array}$ & 0.9997 & 0.003448 \\
\hline
\end{tabular}




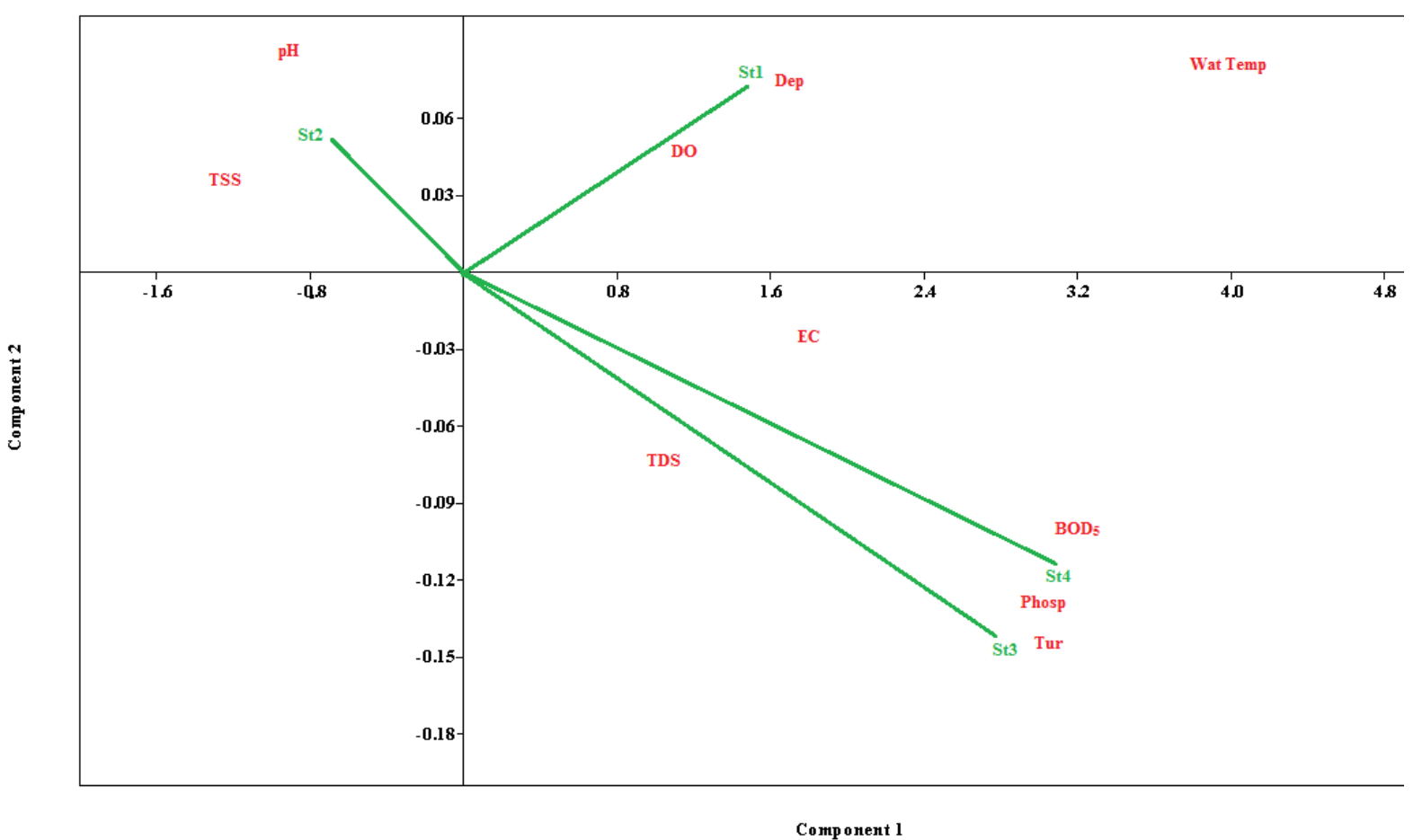

Figure 2: PCA showing correlation matrix between sampled sites and physico-chemical variables in Ojirami Reservoir during the study period (January 2009 - December 2010).

Physico-chemical variables abbreviation: Wat Temp $=$ water temperature, Dep $=$ depth, Tur = turbidity, $\mathrm{EC}=$ electrical conductivity, $\mathrm{DO}=$ dissolved oxygen, $\mathrm{BOD}_{5}=$ five day biochemical oxygen demand, TDS = total dissolved solids, $\mathrm{TSS}=$ total suspended solids, Phosp = phosphate.

\section{Structural assemblage of macroinvertebrates}

Twenty-eight (28) taxa of macroinvertebrate in seven phyla/orders were recorded during the entire study period (Appendix). Order Diptera dominated the macroinvertebrate assemblage represented by nine taxa, followed by Order Ephemeroptera represented by seven taxa. The absolute abundance of Diptera taxa was generally higher at Site 4. Chironomus spp. and Cricotopus spp. were the most preponderant taxa in Site 4 among the recorded Diptera taxa (Appendix). Mollusca taxa absolute abundance were exceptionally higher at Site 4 with Mytilus spp. , having 416 individuals which represent $47.4 \%$ of the total number (878) of macroinvertebrate taxa individuals recorded in Site 4. Sites 1, 2 and 3 had 370, 326 and 408 individual taxa, respectively (Appendix).

On the NMDS computed, macroinvertebrate taxa assemblage in Sites 1 and 2 formed cluster B portraying similarity in the assemblage structure of taxa recorded in Sites 1 and 2 (Figure 3). Cluster $\mathrm{C}$ was formed by taxa assemblages in Sites 3 and 4, and Cluster A formed a mixture of macroinvertebrate taxa assemblages from all the sites sampled with Sites 3 and 4 distinctly forming most of the Cluster A assemblage (Figure 3). 


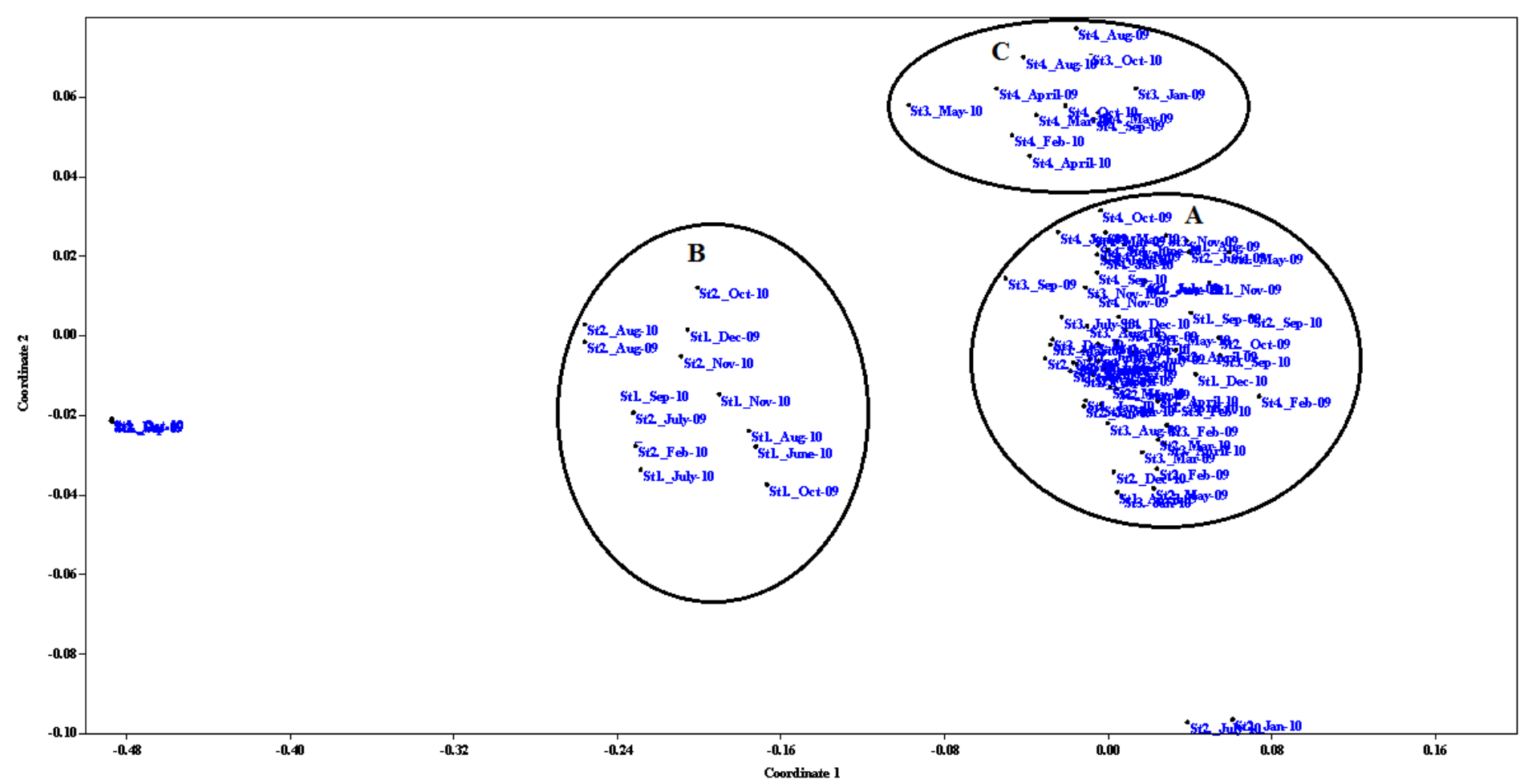

Figure 3: Non-metric multidimensional scaling based on Bray-Curtis similarity index showing clusters of sites based on assemblage of macroinvertebrate taxa in Ojirami Reservoir between January 2009 and December 2010. Cluster A formed mainly samples collected at Sites 1 and 2; Cluster B formed samples collected majorly from Sites 3 and 4 and Cluster C consist mainly of samples collected at Site 4.

\section{Relationship between macroinvertebrate and physico-chemical variables}

The Eigen values of Axes 1 and 2 of the CCA triplot was 0.030 and 0.0013 , respectively (Figure 4). Axis 1 explained $99.56 \%$ of total variance and Axis 2 explained $0.4413 \%$ variance of the CCA biplot. Monte Carlo test at 999 permutation argument revealed a P-value of 0.54 and 0.173 for Axes 1 and 2 respectively which shows that no significant difference existed $(\mathrm{P}>0.05)$ between the first two axes of the CCA biplot, with regards to correlation of macroinvertebrate taxa and physico-chemical variables analysed during the study period. Depth and DO were strongly positively correlated with Caenis spp., Hydrophlebia spp., Strictochironomus spp., Siphlonurus spp., Centroptilum spp. on Axis 1 and Cricotopus spp., Chironomus spp., Corynoneura spp. and Ephemerella spp. were slightly positively correlated with depth and DO in Site 1 on the first axis of the CCA biplot (Figure 4). These taxa were negatively correlated with increasing concentration of turbidity and TSS (Figure 4). Mytilus dubia was strongly positively correlated with turbidity in Site 2 (Figure 4). Increasing concentration of $\mathrm{BOD}_{5}, \mathrm{EC}$ and phosphate were strongly positively correlated with Pseudagrion spp., 
Caridinagabonensis, Corixa spp., Culexpipiensfatigan, Notonecta spp., Ischura spp. and Chaoborus spp. in Sites 3 and 4 on the first CCA axis (Figure 4).

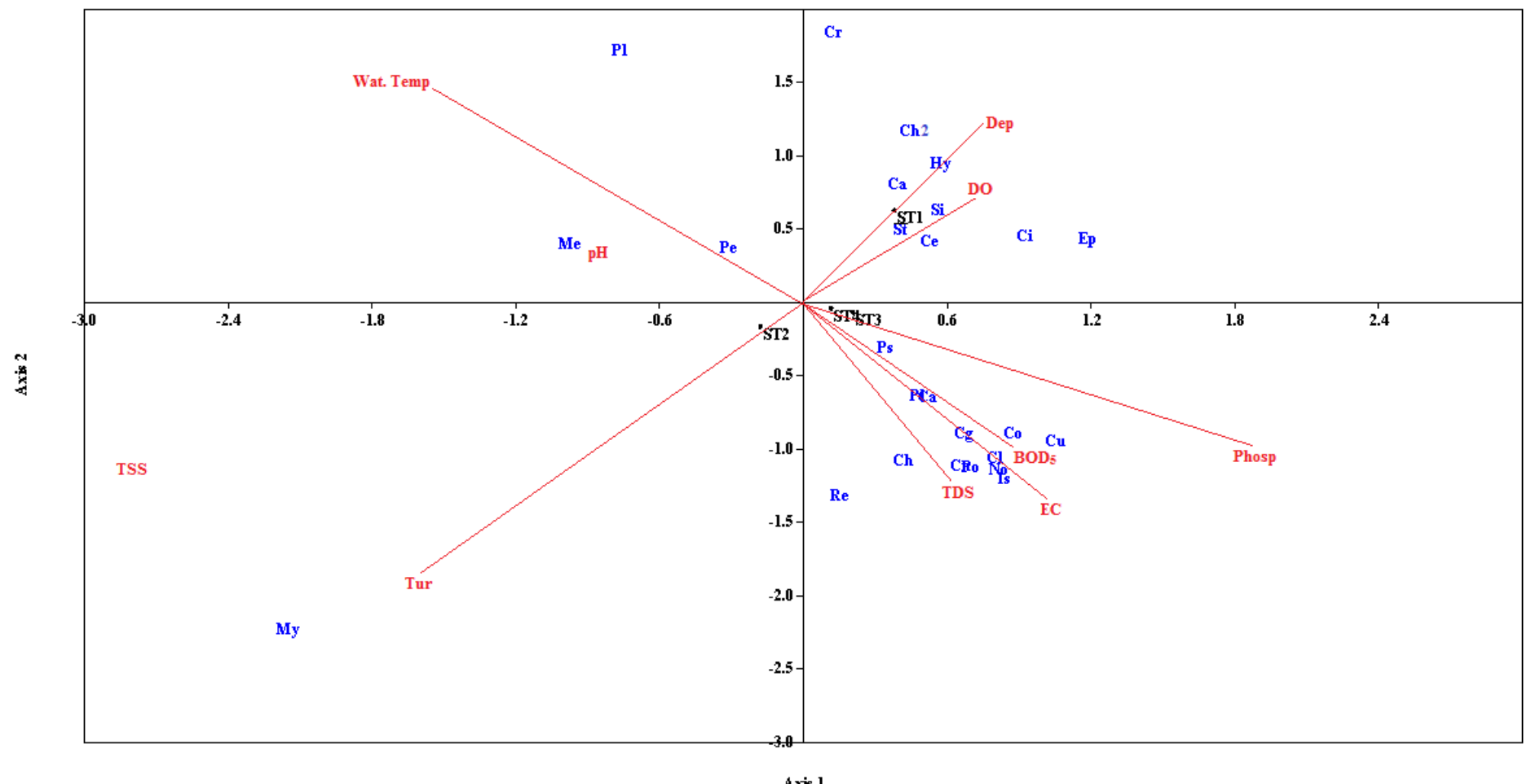

Figure 4: CCA ordination plot showing the first two axes of the correlation between analyzed physico-chemical variables and macroinvertebrate taxa in Ojirami Reservoir during the study period (January 2009 - December 2010). See Table 2 for macroinvertebrate taxa code. Physico-chemical variables abbreviation: Wat Temp $=$ water temperature, Dep $=$ depth, Tur $=$ turbidity, $\mathrm{EC}=$ electrical conductivity, $\mathrm{DO}=$ dissolved oxygen, $\mathrm{BOD}_{5}=$ five day biochemical oxygen demand, TDS $=$ total dissolved solids, TSS $=$ total suspended solids, Phosp $=$ phosphate

\section{Identifying and classifying potential sensitive and tolerant macroinvertebrate taxa}

Potential sensitive and tolerant macroinvertebrate taxa were determined using the taxa coordinate positions along the first axis of the CCA because the first axis of the CCA explained over $99 \%$ of the total variance explained by the CCA first two axes which indicates a good ordination. Taxa were classified from very tolerant (VT) to very sensitive (VS) using a percentile distribution range of $100^{\text {th }}$ and $<10-0^{\text {th }}$, respectively. Mytilus dubia was the only taxon that was classified as very tolerant because it had a $\%$ inter-taxa distance of 100 corresponding to $100^{\text {th }}$ percentile (Table 2). Two taxa; each was classified as tolerant (Melanoides spp. and Corynoneura spp.) and moderately tolerant (Nais spp. and Pentaneura spp. - Table 2).

For the sensitive taxa, only Centroptilum spp. was classified as very sensitive taxon, owing to the fact that it had a $\%$ inter-taxa distance of $0 \%$ corresponding to the percentile distribution range of $<10-0^{\text {th }}$ (Table 2). Strictochironomus spp. and Siphlonurus spp. were both classified as sensitive taxa having \% inter-taxa distance of $13.14376 \%$ and 18.9614 $\%$, respectively, falling into the percentile distribution of $<20-10^{\text {th }}$ (Table 2 ). Overall, more of the recorded macroinvertebrate taxa were classified as moderately sensitive 
(Table 2). Of the 11 taxa classified as moderately sensitive, four were in the Order Diptera which include Protoplasa spp., Cricotopus spp., Chaoburus spp., Culexpipiens fatigan (Table 2). Two taxa, each of which was moderately sensitive in the Orders Odonata, Hemiptera and Ephemeroptera. They include Coenagrion spp. and Ischura spp. for Odonata; Notonecta spp. and Corixa spp. for Hemiptera and Ephemerella spp. and Cleon spp. for Ephemeroptera (Table 2). Caridina gabonensis was the only Crustacea taxon that was moderately sensitive (Table 2 ).

Table 2: Identified and classified macroinvertebrate taxa in Ojirami Reservoir. Taxa biological classes were derived from the coordinate positions of taxa along CCA first axis in Figure 4.

\begin{tabular}{|c|c|c|c|c|c|}
\hline $\begin{array}{l}\text { Macroinvertebrate } \\
\text { taxa }\end{array}$ & $\begin{array}{l}\text { Taxa } \\
\text { code }\end{array}$ & $\begin{array}{l}\text { Coordinates } \\
\text { of taxa on } \\
\text { CCA Axis } 1 \\
\end{array}$ & $\begin{array}{l}\text { Inter-taxa } \\
\text { distance }\end{array}$ & $\begin{array}{l}\text { \% inter-sites } \\
\text { distance }\end{array}$ & $\begin{array}{l}\text { Taxa } \\
\text { biological } \\
\text { class }\end{array}$ \\
\hline Mytilus dubia & My & -1.5837 & 3.3988 & 100 & VT \\
\hline Melanoides spp. & $\mathrm{Me}$ & -1.26505 & 3.08015 & 90.62463 & $\mathrm{~T}$ \\
\hline Corynoneura spp. & $\mathrm{Cr}$ & -1.2518 & 3.0669 & 90.23479 & $\mathrm{~T}$ \\
\hline Polypedilum spp. & Po & -1.16338 & 2.97848 & 87.63328 & MT \\
\hline Nais spp. & $\mathrm{Na}$ & -0.63047 & 2.445567 & 71.95384 & MT \\
\hline Pentaneura spp. & $\mathrm{Pe}$ & -0.55232 & 2.367417 & 69.6545 & ST \\
\hline Hydrophlebia spp. & Hy & -0.42072 & 2.23582 & 65.78263 & ST \\
\hline Chironomus spp. & $\mathrm{Ch} 2$ & -0.07733 & 1.892431 & 55.67938 & ST \\
\hline Caenis spp. & $\mathrm{Ca}$ & 0.092198 & 1.722902 & 50.69148 & ST \\
\hline Pseudagrion spp. & Ps & 0.170669 & 1.644431 & 48.38269 & SS \\
\hline Renatra spp. & $\operatorname{Re}$ & 0.270536 & 1.544564 & 45.44439 & SS \\
\hline Baetis spp. & $\mathrm{Be}$ & 0.328868 & 1.486232 & 43.72814 & SS \\
\hline Plathemis spp. & $\mathrm{Pl}$ & 0.41074 & 1.40436 & 41.31929 & SS \\
\hline Caridina africanus & $\mathrm{Cf}$ & 0.436192 & 1.378908 & 40.57044 & SS \\
\hline Chaoborus spp. & $\mathrm{Ch}$ & 0.496981 & 1.318119 & 38.78189 & MS \\
\hline Cricotopus spp. & $\mathrm{Ci}$ & 0.534401 & 1.280699 & 37.68092 & MS \\
\hline Caridina gabonensis & $\mathrm{Cg}$ & 0.613889 & 1.201211 & 35.34221 & MS \\
\hline Coenagrion spp. & $\mathrm{Cn}$ & 0.672056 & 1.143044 & 33.63081 & MS \\
\hline Protoplasa spp. & Po & 0.703866 & 1.111234 & 32.69489 & MS \\
\hline Notonecta spp. & No & 0.789071 & 1.026029 & 30.18798 & MS \\
\hline Cleon spp. & $\mathrm{Cl}$ & 0.793947 & 1.021153 & 30.04452 & MS \\
\hline Ischura spp. & Is & 0.808573 & 1.006527 & 29.61419 & MS \\
\hline Ephemerella spp. & $\mathrm{Ep}$ & 0.848827 & 0.966273 & 28.42983 & MS \\
\hline Corixa spp. & $\mathrm{Co}$ & 0.869248 & 0.945852 & 27.829 & MS \\
\hline Culexpipiensfatigan & $\mathrm{Cu}$ & 0.992233 & 0.822867 & 24.21052 & MS \\
\hline Siphlonurus spp. & $\mathrm{Si}$ & 1.17064 & 0.64446 & 18.9614 & $\mathrm{~S}$ \\
\hline Strictochironomus spp. & $\mathrm{St}$ & 1.36837 & 0.44673 & 13.14376 & $S$ \\
\hline Centroptilum spp. & $\mathrm{Ce}$ & 1.8151 & 0 & 0 & VS \\
\hline
\end{tabular}

Biological classes: $\mathrm{VT}=$ very tolerant, $\mathrm{T}=$ tolerant, $\mathrm{MT}=$ moderately tolerant, $\mathrm{ST}=$ slightly tolerant, $\mathrm{SS}=$ slightly sensitive, $\mathrm{MS}=$ moderately sensitive, $\mathrm{S}=$ sensitive, $\mathrm{VS}=$ very sensitive. 


\section{DISCUSSION}

\section{Physico-chemical variables}

Potential bioindicator macroinvertebrate taxa were identified and classified in a reservoir in southern Nigeria. Twenty-eight (28) macroinvertebrate taxa were recorded and related to 10 physico-chemical variables using multivariate approach. Elevated pollution indicating physico-chemical variables such as $\mathrm{BOD}_{5}$, nutrient (phosphate) and TSS were recorded in Site 4, which indicate that Site 4 is seriously deteriorating. Elevated values of pollution indicating physico-chemical variables can result in water quality deterioration in freshwater ecosystems by posing potential stress to the structural assemblages of aquatic organisms. Similar studies have stressed on the negative effects of elevated values of pollution indicating physico-chemical variables in freshwater ecosystems located in highly industrialized and urbanized catchment (Odume et al., 2016; Edegbene et al., 2019a). Increasing concentration of nutrienst in freshwater ecosystems can result to eutrophication occasioned by algal bloom and its consequent alteration of the structural assemblage of aquatic organisms (Marchand et al., 2012). The depletion of dissolved oxygen concentration in Site 4 may be explained by increasing concentration of nutrient and other pollution indicating physico-chemical variables in Site 4. Further buttressing the reason for DO concentration depletion in Site 4 in the present study can be explained by the negative correlation of $\mathrm{DO}$ with phosphate, $\mathrm{BOD}_{5}$, turbidity, EC and TDS on the PCA ordination. The elevated human activities in the catchment of Site 4 could be a major contributor to the decreased DO concentration and increased concentration of nutrient and other pollution indicating physico-chemical variables. Similar study has reported elevated values of nutrients, EC, $\mathrm{BOD}_{5}$ and heavy metals in an organic effluent discharge site of a river located in a highly industrialized area (Odume et al., 2016). The strong positive correlation of increasing DO concentration with Site 1 on the PCA is a pointer to the fact that Site 1 is relatively less impacted compared to Sites 4, 3 and 2 .

\section{Macroinvertebrate structural assemblage and selection of potential indicator taxa}

Assessing the ecological health of freshwater ecosystems is of paramount importance as this would aid in biomonitoring, managing and conservation of aquatic biodiversity within freshwater ecosystems. Therefore, a study of this kind which identifies and classifies simple and cost effective potential indicator macroinvertebrate taxa would help in reducing the cost of monitoring freshwater ecosystems, most especially in Sub Sahara Africa that is still behind in the science of developing biomonitoring tools for ecological assessment of freshwater ecosystems. Most developed countries have developed both regional and national biological tools for assessing freshwater ecosystems (Gieswein et al., 2019; Shull $\boldsymbol{e t}$ al., 2019). Reversely is the case for countries in Sub Sahara Africa including Nigeria, as they still engage in the use of aquatic macroinvertebrate taxa abundance and diversity in judging the level of deterioration that freshwater ecosystems are undergoing (Adakole \& Anunne, 2003; Arimoro et al., 2015). In this study, a more sophisticated approach was explored in awarding the level of sensitivity and tolerance of macroinvertebrate taxa to pollution effects. The approach employed in this study has been successfully used to award 
tolerance scores to macroinvertebrate taxa in Europe (Murphy et al., 2013) and South Africa (Odume et al., 2016). Further, Edegbene et al. (2019a; 2020) have also used similar approach in categorizing river sites into pollution impact categories in the Niger Delta area of Nigeria. The multivariate approach employed in the present study will add to and solidify on the existing potential macroinvertebrate taxa that have been suggested to be either sensitive to or tolerant of pollution gradient (Edegbene et al., 2015; Shimba \& Jonah, 2016; Edegbene, 2020).

Earlier studies had reported macroinvertebrate taxonomic metric, percent Ephemeroptera+Plecoptera+Trichoptera (\%EPT) and percent Diptera+Oligochaeta (\%DO) , sensitive to and tolerant of increasing pollution gradient respectively (Andem $\boldsymbol{e t}$ al., 2014; Edegbene et al., 2015). However, the multivariate approach employed in the present study indicated four out of the 11 Diptera taxa recorded to be moderately sensitive, while the taxa include Protoplasa spp., Cricotopus spp., Chaoborus spp. and Culex papiens fatigan. This corroborates with Shimba and Jonah (2016) findings in an agriculturally disturbed river in Tanzania were some taxa in the Order Diptera were reported to be dominant in relatively undisturbed site.

Mytilus dubia (Mollusca) was classified as a very tolerant taxon, while Nais spp. (Annelida) and Melanoides spp. (Mollusca) as tolerant taxa. This is expected as several studies have reported most taxa in the Phyla Mollusca and Annelida to be tolerant of pollution (Andem et al., 2014). The three Hemiptera taxa recorded were either slightly sensitive or moderately sensitive. Hemipterans are mainly predators making them specialist feeders, and their numbers are expected to decrease with increasing concentration of pollution indicating environmental variables (Doledec \& Statzner, 2008). Centroptilum spp. in the Order Ephemeroptera was the only very sensitive taxon among the macroinvertebrate taxa recorded in Ojirami reservoir, and the remaining taxa of the Order Ephemeroptera were slightly sensitive, moderately sensitive and sensitive except for Hydrophlebia spp. and Caenis spp. that were slightly tolerant. Some families of the Order Ephemeroptera; e.g. Baetidae have been reported to be capable of becoming resilience in the face of organic pollution (Merrit $\boldsymbol{e t}$ al., 1996). The ability of Baetidae to feed by collecting-gathering and scrapping of exposed surfaces have been reported to make them confer resilience in polluted freshwater ecosystems (Edegbene $\boldsymbol{e t ~ a l . , ~ 2 0 1 9 b ) . ~}$ Therefore, the classification of Caenis spp. ,as slightly tolerant of pollution, can be explained by its multiple feeding habits just like the baetids.

Overall, the CCA model, showing the relationship between macroinvertebrate taxa and physico-chemical variables along the four sampling sites, further supports the categorization of potential indicator macroinvertebate taxa identified in this study. For example, on the CCA model increasing DO concentration was strongly positively correlated with Centropitilum spp. (very sensitive taxon), Siphlonurus spp. and Strictochironomus spp. (sensitive taxa). On the other hand, Polypedilum spp. (moderately tolerant),Chironomus spp. (slightly tolerant) were positively strongly correlated with increasing pollution indicating physico-chemical variables. 


\section{CONCLUSION}

Potential sensitive and tolerant macroinvertebrate taxa were identified and classified in a reservoir in southern Nigeria. The multivariate approach employed in this study proved effective as the PCA categorized the four sampling sites of the reservoir along a pollution gradient. Site 1 was the less impacted site and Site 4 was the most impacted site. Elevated mean values of nutrient (phosphate), $\mathrm{BOD}_{5}$, turbidity and TDS were noticed in Site 4, further buttressing the level of pollution Site 4 of the reservoir is undergoing. The CCA model computed showed that most of the taxa were deemed moderately sensitive to pollution. Diptera taxa such as Chaoborus spp., Strictochironomus spp., Culex pipiens fatigan and Protoplasa spp. were all moderately sensitive to pollution. Centroptilum spp. (Ephemeroptera) was the only very sensitive taxon, and Mytilus dubia (Mollusca) was the only very tolerant taxon. Overall, the study was able to elucidate the usefulness of identifying and classifying potential biological indicator for effective monitoring and management of freshwater ecosystem, most especially, in Sub Sahara Africa where studies of this kind are still scanty.

\section{ACKNOWLEDGMENTS}

We appreciate the authorities of the Edo State Urban Water Board for granting permission to access the reservoir for the study. We thank the staff of Ojirami Dam, our final year students $(2009 / 2010 ; 2010 / 2011)$ and the technical staff of the Department of Zoology and Biochemistry laboratories of Ambrose Alli University, Ekpoma for field and laboratory assistance.

\section{FUNDING}

This work was partially funded by Ambrose Alli University, Ekpoma, Nigeria, in form of school fee subsidy given to the first author during her doctoral degree programme.

\section{DECLARATION OF INTEREST}

There is no conflicting interest to declare in this work.

\section{AUTHORS' CONTRIBUTION STATEMENT}

Dr. Osimen and Prof. Elakhame conceptualizes the work. Dr. Edegbene design the structure of the manuscript. Dr. Osimen did the macroinvertebrates and physico-chemical variables sampling and analyses. Dr. Edegbene performed the statistical/data analyses. The first draft of the manuscript was written by Dr. Osimen and Dr. Edegbene. Dr. Osimen, Dr. Edegbene and Dr. Izegaegbe reviewed and edited the manuscript and the manuscript was finalized by Dr. Edegbene. Prof. Elakhame supervised the entire work. 


\section{REFERENCES}

Adakole, J.A. and Anunne, P.A. (2003). Benthic macroinvertebrates as indicators of environmental quality of an urban stream in Zaria, Northern Nigeria. Journal of Aquatic Sciences, 18(2): 85 -92.

Adeogun, A.O. and Fafioye, 0.0. (2011). Impact of effluent on water quality and benthic macroinvertebrate fauna of Awba Stream and Reservoir. Journal of Applied Science and Environmental Management, 15(1): 105 - 115.

Adesina, G.O.; Daddy, E.; Aina, E. and Ajibola, A.T. (2010). Current status and flouristic diversity of aquatic macrophytes of two freshwater bodies in Southern Nigeria. American-Eurasian Journal Agriculture and Environmental Science, 7(5): $571-576$.

Andem, A.B.; Okorafor, K.A.; Eyo, V.O. and Ekpo, P.B. (2014). Ecological impact assessment and limnological characterization in the intertidal region of Calabar River using benthic macroinvertebrates as bioindicator organisms. International Journal of Fisheries and Aquatic Studies, 1(2): 8-14.

APHA (American Public Heath Association) (1998). Standard Methods for the Examination of Water and Wastewater, WEF and AWWA, 20th Edition, USA. $1213 \mathrm{Pp}$.

Arimoro, F.O.; Odume, O.N.; Uhunoma, S.I. and Edegbene, A.O. (2015). Anthropogenic impact on water chemistry and benthic macroinvertebrate associated changes in a southern Nigeria stream. Environmental Monitoring and Assessment, 187(2): $1-14$.

Bonada, N.; Prat, N.; Resh, V.H. and Statzner, B. (2006). Development in aquatic insect biomonitoring: A comparative analysis of recent approaches. Annual Review of Entomology 51: 495 - 523.

Day, J.A.; Harrison, A.D and de Moore, I.J. (2003). Guides to Freshwater Invertebrates of Southern Africa, Volume 9. Water Research Commission Report No. TT 201/02. 200pp

de Moore, I.J.; Day J.A. and de Moore, F.C. (2003). Guides to Freshwater Invertebrates of Southern Africa, Volume 9. Water Research Commission Report No. TT 207/03. 288pp

Derrick, B.; Ruck, A.; Toher, D. and White, P. (2018). Tests for equality of variances between two samples which contain both paired observations and independent observations. Journal of Applied Quantitative Methods, 13 (2): 36-47. 
Dickens, C.W.S. and Graham, P.M. (2002). The South African Scoring System (SASS) version 5 rapid bioassessment method for rivers. African Journal of Aquatic Science, 27: 1 - 10.

Dolédec, S. and Statzner, B. (2008). Invertebrate traits for the biomonitoring of large European rivers: an assessment of specific types of human impact. Freshwater Biology, 53: $617-634$.

Edegbene, A.O. (2020). Potential menace posed by invasive grass and water quality deterioration on macroinvertebrates structural distribution in a dam in NorthWestern Nigeria. Water Science, 34(1), 75 - 84.

Edegbene, A.O.; Arimoro, F.O. and Odume, O.N. (2019a). Developing and applying a macroinvertebrate-based multimetric index for urban rivers in the Niger Delta, Nigeria. Ecology and Evolution, 9: 12869-12885.

Edegbene, A.O. and Arimoro, F.O. (2012). Ecological Status of Owan River, Southern Nigeria Using Aquatic Insects as Bioindicators. Journal of Aquatic Sciences, 27: $99-111$.

Edegbene, A.O., Arimoro, F.O. and Odume, F.O. (2020a). How does urban pollution influence macroinvertebrate traits in forested riverine systems? Water. DOI:10.3390/w12113111

Edegbene, A.O.; Arimoro, F.O. and Odume, O.N. (2020b). Exploring the distribution patterns of macroinvertebrate signature traits and ecological preferences and their responses to urban and agricultural pollution in selected rivers in the Niger Delta ecoregion, Nigeria. Aquatic Ecology, 9: 12869 - 12885.

Edegbene, A.O.; Arimoro, F.O.; Odoh, O. and Ogidiaka, E. (2015). Effect of anthropogenicity on the composition and diversity of aquatic insects of a municipal river in North Central Nigeria. Biosciences Research in Today's World, 1: $69-80$.

Edegbene, A.O.; Elakhame, L.A.; Arimoro, F.O.; Osimen, E.C. and Odume, O.N. (2019b). Development of Macroinvertebrates Multimetric Index for Ecological Evaluation of a River in North Central Nigeria. Environmental Monitoring and Assessment 191(5): 274. https://doi.org/10.1007/s10661-019-7438-8.

Gieswein, A.; Hering, D. and Lorens, A.W. (2019). Development and validation of a macroinvertebrate-based biomonitoring tool to assess fine sediment impact in small mountain streams. Science of the Total Environment, 652: 1290 -1301.

Hammer, Ø.; Harper, D. A. T. and Ryan, P. D. (2001). PAST: paleontological statistics software package for education and data analysis. Palaeontologia Electronica 4(1): 9Pp. http://palaeo-electronica.org/2001_1/past/issue1_01.htm Accessed 1 July 2015 
Kaaya, L.T.; Day, J.A. and Dallas, H.F. (2015). Tanzania river scoring system (TARISS): a macroinvertebrate-based biotic index for rapid bioassessment or rivers. African Journal of Aquatic Science, 40(2): 109-117.

Katsiapi, M.; Moustaka-Gouni, M. and Sommer, U. (2016). Assessing ecological water quality of freshwaters: Phycol-a new phytoplankton community index. Ecological Information, 31: 22-29.

Lazorchak, J.M.; Klemm, D.J. and Peck, D.V. (1998). Environmental monitoring and assessment program surface waters: field operations and methods manual for measuring the ecological condition of wadeable streams. EPA 620/R-94/004F. Washington , D.C. U.S. Environmental Protection Agency.

Legendre, P. and Legendre, L. (2012). Numerical Ecology. Development in environmental modelling, 3rd edition. Vol.24, Elsevier science BV, Amsterdam $1006 \mathrm{Pp}$.

Lenat, D.R. and Resh, V.H. (2001). Taxonomy and stream ecology: The benefits of genus-and species-level identifications. Journal of North American Benthological Society, 20 (2): 287 - 298.

Marchand, M.J.; van Dyk, J.C.; Barnhorn, I.E.J. and Wagenaar, G.M. (2012). Histological changes in two potential indicator fish species from a hypereutrophic fresh-water ecosystem in South Africa: a baseline study. African Journal of Aquatic Science, 37 (1): 39-48.

Merritt, R.W. and Cummins, K.W. (1996). An introduction to the aquatic insects of North America (3rd ed.). Dubuque, J.O: Kendall-Hunt. 862Pp.

Merritt, R. W.; Wallace, J. R.; Higgins, M. J.; Alexander, M. K.; Berg, M. B.; Morgan, W. T., ... Vandeneeden, B. (1996). Procedures for the functional analysis of invertebrate communities of the Kissimmee river floodplain ecosystem. Florida Scientist, 59: 216-274.

Murphy, J.F.; Davy-Bowker, J.; McFarland, B. and Ormerod, S.J. (2013). A diagnostic biotic index for assessing acidity in sensitive streams in Britain. Ecological Indicators, 24: 562-572.

Odume, O.N.; Palmer, C.G.; Arimoro, F.O. and Mensah, P.K. (2016). Chironomid assemblage structure and morphological response topollution in an effluentimpacted river, Eastern Cape, South Africa. Ecological Indicators, 67: 391 - 402.

Ogidiaka, E.; Asagbra, M.C.; Arimoro, F.O. and Edegbene, A.O. (2013). Non-cichlid fish communities of Warri River at Agbarho, Niger Delta Area, Nigeria. Journal of Aquatic Sciences, 28(1): 17 -23.

Oksanen, J.; Blanchet, D.; Minchin, P.R.; O’Hara, R.B.; Simpson, G.L.; Solymos, P.; Steven, M.H.M.; Szoecs, E. and Wagner, H. (2019). Vegan: Community 
Ecology Package. Retrieved 11/02/2019 from https://cran.rproject.org,https://github.com/veganders/vegan. Published 04-02-2019, 11:50:04 UTC.

Osimen, E.C.; Elakhame, L. A. and Ogbeibu, A.E. (2017). Dynamics of the zooplankton assemblage of Ojirami Reservoir, Edo state, Nigeria. Tropical Freshwater Biology, 25: 1 - 16.

Palmer, C.G.; Berold, R. and Muller, W.J. (2004). Environmental Water Quality in Water Resource Management, WRC Report No. TT 217/04. Water Research Commission, Pretoria.

Parienté, W. (2017). Urbanisation in Sub-Saharan Africa and challenges of access to basic services. Journal of Demographic Economics 83, (1): 31 - 39.

R Development Core Team. (2019). R statistical computing environment. Vienna, Austria: R Foundation for Statistical Computing. ISBN 3- 900051-07-0, URL http://www.R-project.org

Shimba, M.J. and Jonah, F.E. (2016). Macroinvertebrates as bioindicators of water quality in the Mkondoa River, Tanzania, in an agricultural area. African Journal of Aquatic Science, 41: 1-9.

Shull, D.R.; Smith, Z.M. and Selckmann, G.M. (2019). Development of a benthic macroinvertebrate multimeric index for large semiwadeable rivers in the MidAtlantic region of the USA. Environmental Monitoring and Assessment, 191(1): 22. https://doi.org/10.1007/s10661-018-7153-x.

ter Braak, C.J.F. (1995). Ordination. In: Jongman, R.H.J, terBraak, C.J.F. and van Tongeren, O.F.R. (Eds). Data analysis in community and landscape ecology. Cambridge University Press, Cambridge, UK: 91 - 173.

Walley, W.J. and Hawkes, H.A. (1996). A computer-based reappraisal of the biological monitoring working party scores using data from the 1990 river quality survey of England and Wales. Water Research 30: 2086 - 2094. 


\section{APPENDIX}

Appendix: Structural assemblage of macroinvertebrates in Ojirami Reservoir, Edo State, Nigeria during the study period (January 2009 - December 2010)

\begin{tabular}{|c|c|c|c|c|c|}
\hline Phylum/Order & Taxa & Site 1 & Site 2 & Site 3 & Site 4 \\
\hline Annelida & Nais spp. & 0 & 8 & 18 & 38 \\
\hline \multirow[t]{7}{*}{ Ephemeroptera } & Beatis spp. & 24 & 14 & 19 & 12 \\
\hline & Ephemerella spp. & 7 & 7 & 17 & 13 \\
\hline & Siphlonurus spp. & 0 & 2 & 2 & 9 \\
\hline & Caenis spp. & 45 & 31 & 25 & 29 \\
\hline & Centroptilum spp. & 13 & 7 & 0 & 0 \\
\hline & Cleon spp. & 5 & 4 & 5 & 0 \\
\hline & Hydrophlebia spp. & 8 & 0 & 0 & 0 \\
\hline \multirow[t]{3}{*}{ Hemiptera } & Renatra spp. & 0 & 3 & 0 & 0 \\
\hline & Corixa spp. & 4 & 0 & 3 & 0 \\
\hline & Notonecta spp. & 0 & 0 & 0 & 2 \\
\hline \multirow[t]{4}{*}{ Odonata } & Plathemis spp. & 3 & 0 & 0 & 0 \\
\hline & Pseudagrion spp. & 7 & 2 & 0 & 4 \\
\hline & Coenagrion spp. & 0 & 5 & 5 & 5 \\
\hline & Ischura spp. & 0 & 3 & 3 & 9 \\
\hline \multirow[t]{9}{*}{ Diptera } & Chironomus spp. & 48 & 21 & 30 & 87 \\
\hline & Polypedilum spp. & 45 & 18 & 16 & 3 \\
\hline & Strictochironomus spp. & 8 & 4 & 30 & 26 \\
\hline & Protoplasa spp. & 0 & 0 & 0 & 1 \\
\hline & Corynoneura spp. & 27 & 22 & 0 & 2 \\
\hline & Cricotopus spp. & 23 & 8 & 22 & 27 \\
\hline & Pentaneura spp. & 26 & 15 & 5 & 10 \\
\hline & Chaoborus spp. & 0 & 7 & 7 & 0 \\
\hline & Culex pipiens fatigan & 0 & 0 & 7 & 6 \\
\hline \multirow[t]{2}{*}{ Crustacea } & Caridina africanus & 6 & 0 & 0 & 1 \\
\hline & Caridina gabonensis & 3 & 0 & 0 & 3 \\
\hline \multirow[t]{2}{*}{ Mollusca } & Melanoides & 68 & 145 & 194 & 175 \\
\hline & Mytilus dubia & 0 & 0 & 0 & 416 \\
\hline Total no. of taxa & & 370 & 326 & 408 & 878 \\
\hline
\end{tabular}

